\title{
LICENSING AND LEGALIZATION OF TRADITIONAL MEDICINE TO ENSURE PUBLIC HEALTH QUALITY ${ }^{\Omega}$
}

\author{
Lilik Pudjiastuti \\ Law Faculty Airlangga University \\ E-mail: pudjiastutililik@yahoo.com
}

\begin{abstract}
Traditional medicine is a form of pharmaceutical ingredient which uses as medicine by the people. In public paradigm, traditional medicines is considering more secure and cheaper compare with patent medicine. The reason of such condition due to traditional medicines are made from materials of plants, animals, mineral galenic ingredients or mix of all those ingredients hereditary. In Indonesia the instrument control of traditional medicine conducted by regulation, license, supervision and legal enforcement. In practical, based on the surveillance result which conducted by BPOM found from 7.605 sample of traditional medicine, $1.867(24.55 \%)$ of those are not fulfilled the standard because several reasons contain chemical ingredients, does not have distribution license, has long wrecked time and has unsuitable water content. This condition resulted due to the lack of ability of traditional medicine business to fulfill the requirement and obligation of license owner to conduct the medicine manufacture base on CPOTB.
\end{abstract}

Key words: traditional medicine, license, legal enforcement.

\begin{abstract}
Abstrak
Obat tradisional merupakan salah satu bentuk sediaan farmasi yang digunakan sebagai pengobatan oleh masyarakat. Dalam aspek sosial masyarakat, terdapat Paradigma bahwa obat tradisional dianggap lebih aman dan murah dibandingkan dengan obat paten, hal ini dikarenakan obat tradisional terbuat dari bahan atau ramuan yang berupa bahan tumbuhan, bahan hewan, bahan mineral, sediaan sarian (galenik), atau campuran dari bahan tersebut yang digunakan secara turun temurun. Pengendalian keamanan obat tradisional di Indonesia dilakukan dengan peraturan perundang-undangan, perizinan, pembinaan, pengawasan dan penegakan hukum. Berdasarkan hasil pengawasan yang dilakukan oleh BPOM diperoleh hasil bahwa dari 7.605 sampel obat tradisional ditemukan 1.867 (24,55\%) obat tradisional dinyatakan tidak memenuhi syarat karena obat tradisional tersebut mengandung bahan kimia, tidak memiliki izin edar, memiliki waktu hancur yang lama serta memiliki kadar air yang tidak sesuai. Hal ini disebabkan ketidakmampuan dari usaha obat tradisional untuk memenuhi persyaratan dan kewajiban pemegang izin untuk melakukan pembuatan obat sesuai dengan CPOTB.
\end{abstract}

Kata kunci: obat tradisional, perizinan, penegakan hukum.

\section{Introduction}

Health service practices using traditional medicine (read: OT) is very popular among society, this is no other caused by the stigma that marks OT as more safety, with no side effect and less expensive. These strong beliefs are mainly affected by the fact that OT are made of plants,

$\Omega \quad$ Reasearch result, skim leading research Universities year 2014, Funded by DIPA BOPTN Fiscal year 2014 in accordance with The Decree of Airlangga University Rector on Research Desentralization Activity-Leading Research Universities No: $965 /$ UN3/2014, Date on Februari, $28^{\text {th }}$ 2014 animals and minerals which are abundant as Indonesia's natural resources. Currently, there are about 13.000 brands of pharmaceutical product in form of modern and traditional medicine can be found in any markets. All those are produced by approximately 247 drug manufacturers. ${ }^{1}$

Hana Nika Rustia, Kontroversi Legalitas Praktik Kefarmasian Oleh Tenaga Keperawatan, Aspiration Journal, Vol. 1, No. 1, June 2010, Jakarta: Secretariat-General DPR RI, page 51. 
Government, who hold the power within the nation are supposed to rule its society, specifically, in supervising the distribution of OT to maintain public health quality. Until today, there is no clear guarantee towards the safety and benefit of many OT products distributed among society. It is shown by several circular letter issued by National Agency of Food and Drug Control (BPOM) to warn the society (public warning) towards several OT products, both imported and domestic ones.

In addition, government are responsible to guarantee the quality, safety, benefit and affordability of OT. Government have set some control instruments of OT which are related to laws and regulation, license, supervision and legal enforcement. According to BPOM surveillance in 2010 towards 7.605 OT samples, there are $1.867(24,55 \%)$ of the samples didn't meet the requirement of the chemical ingredients, drugs wrecked-time, and water content. ${ }^{2}$ This is, however, proves the weakness of government in maintaining the quality of traditional medicine (OT) within society.

\section{Research Problem}

Based on the problem proposed above, there are several points need to be answered as follows: first, what is the control instrument used by government to maintain the distribution of safe and good quality of traditional medicine?; and second, how to strengthen law enforcement in controlling traditional medicine industriesmanufacturers?

\section{Research Method}

In accordance to the problem, this study used socio-legal method which examines the implementation of current laws and regulation towards certain cases of traditional medicine

2 Agency for Food and Drug Administration, 2011, Food and Drug Administration profile in 2010, 2011, Jakarta: Mi-nistry of Healthh, page 6.

3 Salmen Sembiring, "Pengetahuan dan Pemanfaatan Metode Pengobatan Tradisional Pada Masyarakat Desa Suka Nalu Kecamatan Barusjahe", Jurnal Perspektif Sosiologi, Vol. I, No. 1, 2013, Medan: Universitas Sumatera Utara, page 12.

4 Kristiono R.S. Yuniar Wardani, “Faktor-Faktor yang Berhubungan dengan Pola Pencarian Pengobatan ke Pelaya-
(OT). This method used several approaches including laws and regulation approach, conceptual approach and historical approach.

There are several variables involved to understand the distribution of traditional medicine: fundamental rights of people to get health services include the need of medicines/traditional medicines, it is absolutely needed to meet the requirements of safety, quality and efficacy as a part of National Healthcare System; Social point of view that stigmatize OT is way safer than patent medicines. Economic point of view, OT is less expensive compared to patent medicines; as well as government roles and functions in supervising and controlling OT. Using those three approaches, this study is expected to gain a comprehensive result to create a better policies that maintain OT in Indonesia.

\section{Discussion}

\section{Control Instruments of Traditional Medicines}

Traditional medicines are part of pharmaceutical product mostly used by people, this is because traditional medicines (OT) practices are very popular among society and are mainly passed through an interaction within families, among neighborhood and among patients. ${ }^{3}$ This condition is also the result of Indonesian culture which relies most healthcare action within family towards housewife who prefers alternative or traditional medicine and will mostly uses those kind of medication. ${ }^{4}$

Many OT are sold in form of capsules, powders, liquid and tablets. Based on the ingredients of the product, OT and modern medicines have several differences shown in the following table. ${ }^{5}$ Based on the ingredients, OT are divided into 3 groups. First, Jamu, is a potion used to treat certain disease and maintain health, passed down through generations, e.g. Tolak Angin.

nan Kesehatan Alternatif Pasien Suspek Tuberculosis Di Komunitas", Jurnal Kesehatan Masyarakat, Vol. 7, No. 2, September 2013, Yogyakarta: Universitas Ahmad Dahlan, page 60 .

Hedi R. Dewoto, "Pengembangan Obat Tradisional Indonesia Menjadi Fitofarmaka”, Indonesian Medical Magazine, Vol. 57, No. 7, July 2007, Jakarta: Indonesian Doctors Association, page 207. 
Second, Standardized herbal medicines is pharmaceutical product made of standardized natural compounds and is pre-clinically tested, e.g. Diapet. Third, Phytopharmaco is kind of OT equivalent to modern medicines. It uses standardized production method and has been clinically tested on human, it also has some scientific proof, e.g. Stimuno. ${ }^{6}$

Tabel 1. Comparative of OT/Herbal Medicines and Modern Medicines

\begin{tabular}{|l|l|l|}
\hline Differeces of OT/Herbal Medicines and Modern Medicines \\
\hline & \multicolumn{1}{|c|}{$\begin{array}{c}\text { Modern } \\
\text { Medicines }\end{array}$} & \multicolumn{1}{|c|}{$\begin{array}{c}\text { Traditional } \\
\text { Medicines }\end{array}$} \\
\hline $\begin{array}{l}\text { Chemical } \\
\text { contents }\end{array}$ & $\begin{array}{l}\text { One or more are } \\
\text { purified/synthetic }\end{array}$ & $\begin{array}{l}\text { Mix of many } \\
\text { natural compound }\end{array}$ \\
\hline Active agent & Well-known & $\begin{array}{l}\text { Moostly } \\
\text { unspecified }\end{array}$ \\
\hline Quality control & Qite easy & Very difficult \\
\hline $\begin{array}{l}\text { Effectivity and } \\
\text { savety }\end{array}$ & $\begin{array}{l}\text { Clinically tested, } \\
\text { scientific proof }\end{array}$ & $\begin{array}{l}\text { Moostly untested } \\
\text { no scientific proof }\end{array}$ \\
\hline
\end{tabular}

According to WHO, there are 3 ways of acknowledgement and usage of OT within health care system, they are Integrative System (joint health services), Inclusive (unintegrated) and tolerant (allowed). ${ }^{7}$ Consumption of OT in Indonesia start to increase. Regarding to PP No. 103 of 2014 concerning Traditional Health Services, Indonesia's Healthcare System is classified into integrative system. However, the usage of OT should be covered by protection towards society to maximize its benefits, as well as its safety for public health.

Under Act 28 I paragraph 4 of Indonesia's 1945 Constitution, Government is responsible in protecting, developing, giving law enforcement and fulfilling the rights of people. Thereby, Government is responsible to fulfill right to gain health service, as well as the right to work and right to have a proper life. In addition, there should be a regulation that fulfills rights of the patient and rights of OT business actors thus creating balance altogether.

Government can use their instrument of power to create such balance through legal ac-

Hemani, "Pengembangan Biofarmaka sebagai Obat Herbal untuk Kesehatan", Bulletin of Agricultural Postharvest Technology, Vol. 7, No. 1, 2011, Bogor: Bogor Agricultural Institute, page 22.

7 Sampurno, "Obat Herbal dalam Prespektif Medik dan Bisnis", Journal of Traditional Medicine Magazine, Vol. 12, No. 4, 2007, Yogyakarta: Gadjah Mada University, page 3. tion and real action. The key role of government within pharmacy sector is explained by Richard A Abood: as health professionals, pharmacists are highly regulated because the slightest misstep in drug distribution or pharmaceutical care could cost a life. ${ }^{8}$

Legal action to control OT can be implemented through laws and regulation, license and legalization, and law enforcement. Laws and regulation about OT includes: Government Regulation No. 72 of 1998 concerning Security of Pharmaceutical Materials and Medical Tools; Ministerial Regulation No. 06 of 2012 concerning Retigstration and Regulation from Head of Indonesia's National Agency of Food and Drug Control No. HK.03.1.23.06.11.5629 of 2011 concerning Technical Requirements of Making Traditional Medicines.

Legalization is government institrument to control certain activities, as well as giving legal protection. Production and distribution of OT in Indonesia needs approval from several partes shown in following chart:

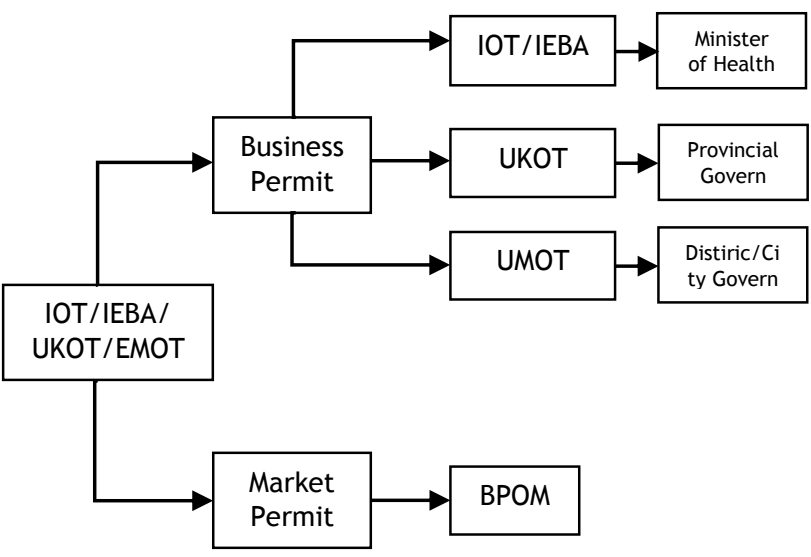

Marketing Permit of Traditional Medicines

Traditional medicines products that is proven for its benefits and safety for human are allowed to be produced by industries as a legal drug and distributed under certain trademarks. ${ }^{9}$ According to Ministerial Regulation No. 07 of

8 Richard Abood, 2008, Pharmacy Practice and The Law, Fifth Edition, Canada: Jones and Bartlett Publishers, page 10.

9 Mae Sri Hartati Wahyuningsih, "Deskripsi Penelitian Dasar Herbal Medicine", Journal of Traditional Medicine Magazine, Vol. 6, No. 2, 2007, Yogyakarta: Gadjah Mada University, page 4 . 
2012 concerning Registration of Traditional Medicines, permission which is given to OT that is proven for its benefits and safety is called marketing permit. This permit can be obtained by proposing the product to the head of BPOM following registration and evaluation procedure. Each OT businessman who wants to register their product must fulfill the requirements that can be seen in the following table.

Tabel 2. List completeness of registration must be completed by the OT businessman to obtain a distribution licence

\begin{tabular}{|c|c|c|c|}
\hline DATA & $\begin{array}{l}\text { DOMESTIC } \\
\text { PRODUCT }\end{array}$ & $\begin{array}{l}\text { LICENSED } \\
\text { PRODUCT }\end{array}$ & $\begin{array}{l}\text { RENTED } \\
\text { PRODUCT }\end{array}$ \\
\hline $\begin{array}{l}\text { Adminis- } \\
\text { trative }\end{array}$ & $\begin{array}{l}\text { - Industrial } \\
\text { permint for } \\
\text { OT/pharmacy } \\
\text { industry; } \\
\text { - Certificate of } \\
\text { CPOTB }\end{array}$ & $\begin{array}{l}\text { - Industrial } \\
\text { permint for } \\
\text { OT/pharmacy } \\
\text { industry; } \\
\text { - Industrial } \\
\text { permit as } \\
\text { license } \\
\text { receiver } \\
\text { - CHS } \\
\text { - CGMP } \\
\text { - License } \\
\text { agreement }\end{array}$ & $\begin{array}{ll}\text { - Industrial } \\
\text { permint for } \\
\text { OT/pharmacy } \\
\text { industry; } \\
\text { - Industrial } \\
\text { permit as } \\
\text { license } \\
\text { receiver } \\
\text { - CGMP } \\
\text { - } \text { Rental } \\
\text { agreement }\end{array}$ \\
\hline Technical & $\begin{array}{ll}\text { - } & \text { Quality } \\
& \text { requirement } \\
\text { - } & \text { SOP }\end{array}$ & $\begin{array}{l}\text { - } \text { Quality } \\
\text { requirement } \\
\text { - SOP }\end{array}$ & $\begin{array}{ll}\text { - } & \text { Quality } \\
& \text { requirement } \\
\text { - } & \text { SOP }\end{array}$ \\
\hline
\end{tabular}

OT distributed throughout society are of domestic production and imported ones. Whereas, each of them should has marketing permit issued by BPOM in Central Government. Based on the number of public warning issued by BPOM, there are many OT that doesn't have marketing permit or being faked. This condition is caused of: first, Ministerial Regulation regulates production and distribution of OT only by pharmacy industries, contrarily, there are many OT produced and distributed by Small Enterprise of Traditional Medicine (UKOT) and Micro Enterprise of Traditional Medicine (UMOT) which are categorized as Small, Micro, and Medium Enterprises (UMKM), therefore both administrative and technical requirements remains a big problem for them; and second, one of the procedure to obtain marketing permit is evaluation/test funded by owner of the product. It gives big economic burden towards the businessman.

Seeing those conditions, Ministerial Regulation No. 7 of 2012 concerning Registration of Marketing Permit cannot guarantee the safety, quality and efficacy of OT product for public health. It can be worse if BPOM unable to supervise and diminish OT listed in public warning.

\section{Business License of Traditional Medicines}

Ministerial Regulation No. 06 of 2012 concerning Industries and Business of Traditional Medicines stated each and every industry and business of OT must possess Business License of Traditional Medicine. The goal is to ensure OT production following the procedure in CРОTВ, but there is an exception for business of handmade jamu.

OT industries, in fact have many flaws in legality. Some might have no complete license and some other might have no license at all. This is because the high cost of technical requirements which require good facilities and tools. This condition remains a big problem for government to control the quality of OT. Regulation of Minister of Health No. 6 of 2012 is hence unable to guarantee OT production as in the CPOTB.

\section{Employment License}

In order to ensure the quality and benefits of OT, each and every OT industries (IOT) and UKOT must follows the CPOTB. It is clearly stated in Regulation of Head of Indonesian National Agency of Drug and Food Control No. HK.03.1. 23.06.11.5629 of 2011 concerning Technical Requirements of CРOTB. One of the requirements within CPOTB is that each and every IOT and Industry of Food Extract (IEBA) must have at least 1 pharmacist of Indonesian citizenship as the director, while UKOT must have at least 1 pharmacist of Indonesian citizenship who possess CPOTB certificate as the director. This way, every OT production are always supervised by a pharmacist.

In fact, the requirement to have pharmacist employee is usually deemed as an administrative thing, while the production of OT remains unsupervised. Again, this is because the producers of OT like UKOT and UMOT are unable to pay the hiring cost, thus there are cases of 1 pharmacist name being used by multiple UKOT and UMOT. This condition will be worse if government fails to control the role of pharmacist in OT production. This condition shows that re- 
quirement of employee in Regulation of Minister of Health no. 6 of 2012 is unable to guarantee the safety, quality and benefits of OT.

Based on the analysis above, there are several flaws within laws and regulations concerning in licensing and legalization of OT that makes guarantee towards safety, quality, benefits and affordability of OT remains unclear. The flows are listed below: firts, OT are produced and distributed by unqualified enterprise; second, low supervision from government towards OT production and circulation within society; third, insufficient information and education of society related with public warning; and fourth, Regulations of OT are beleids regel (discretion) in form of ministerial regulation and regulation of head of BPOM thus are contrary with principles of law making, especially principles of law making institution. Simply, it complicates the implementation of criminal sanction since beleids regel are unable to do that.

\section{Law Enforcement of Production and Marketing of Traditional Medicines Supervision}

Law enforcement towards licensing and legalization of OT production and distribution can be done by implementing law enforcement toward administrative and criminal code. Law enforcement of administrative code has preventive and repressive scope. Supervision is part of the preventive scope, while sanction is repressive scope since it aims to stop and end the violation.

Basically supervision power lays on the power to control OT industries through a sequence of business activities like production, distribution, CPOTB, registration and marketing license. It is committed by government. Supervision can be more powerful by involving society, as consumer or else as businessman. It will leads to the fulfilment of the rights from both parties and creating good atmosphere in business. ${ }^{10}$ Supervision towards OT advertisement by BPOM inclu-

10 Rudy Susanto, Faisal Abdullah and Sabir Alwy, "Pengawasan Peredaran Obat Tradisional di Singkawang", Law Research Journal, Vol, 2, No. 2, 2013, Makassar: Hasanudin University, page 177. des following points: first, Inspection towards marketing license of OT, which examine the quality of OT marketing through 2 stages: premarket inspection and post-market inspection; second, Inspection towards OT production facilities, which is inspection toward implementation of CPOTB. According to report of BPOM in 2013, obtained the following data. ${ }^{11}$

Tabel 3. The result of inspection of toward implementation of CPOTB.

\begin{tabular}{|c|c|c|c|l|}
\hline Year & $\begin{array}{c}\text { Business type } \\
\text { (IOT \& IKOT) }\end{array}$ & MK & TMK & \multicolumn{1}{|c|}{ Information } \\
\hline 2013 & 309 samples & 55 & 244 & $\begin{array}{l}\text { 2 BKO, 43 TIE, 38 } \\
\text { Improrer sanitation, 58 } \\
\text { unlicensed, 17 disobey } \\
\text { administration and 38 } \\
\text { other }\end{array}$ \\
\hline 2014 & 42 samples & 12 & 30 & $\begin{array}{l}\text { 2 TIE, 25 disobey CPO- } \\
\text { TB, 1 disobey making, } \\
\text { 2 disobey administra- } \\
\text { tion }\end{array}$ \\
\hline
\end{tabular}

Third, Inspection towards OT distribution facilities which inspect OT circulation within society. The following data are obtained from BPOM report; ${ }^{12}$

Tabel 4. The result of inspection toward OT distribution in society

\begin{tabular}{|l|c|c|c|l|}
\hline Year & $\begin{array}{c}\text { Circulating } \\
\text { OT }\end{array}$ & MK & TMK & Information \\
\hline 2013 & 2.630 & 1.505 & 1.125 & $\begin{array}{l}\text { Advance by } \\
\text { pulverization BKO, } \\
\text { unlicensed, OT } \\
\text { wrecked/expired }\end{array}$ \\
\hline $\begin{array}{l}\text { 2014 Tri } \\
\text { wulan I }\end{array}$ & 463 & 243 & 220 & \\
\hline
\end{tabular}

Fourth, Inspection towards OT advertisement which inspects OT ads. in any media such as television, radio, leaflet, etc. This is done through pre-review stage and post-review stage. The result of this inspection shown as follow; ${ }^{13}$

Tabel 5 The result of inspection toward OT advertisement in media.

\begin{tabular}{|c|c|c|c|c|c|c|c|}
\hline \multicolumn{3}{|c|}{ Result of pre-review } & \multicolumn{4}{c|}{ Result of post-review } \\
\hline Sample & Approved & Unapproved & Renised & Sample & MK & TMK & Information \\
\hline 110 & 77 & 18 & 15 & 969 & 547 & 42 & $\begin{array}{l}\text { Pinted Hedta, TV, } \\
\text { racio, leaflet, etc }\end{array}$ \\
\hline
\end{tabular}

Advertisements are very crucial in product selling. The effectivity of marketing program can

11 BPOM, 2014, Laporan Kinerja Badan Pengawasan Obat dan Makanan (BPOM) tahun 2013 dan Triwulan I Tahun 2014, Jakarta: Ministry of Health of RI, page 12

12 Ibid, page 13

13 Ibid, page 15 
be fully reached by synergizing MPR and ads., on the other hand marketing are great support for advertising activities. ${ }^{14}$ The result above shows that supervision towards advertisements is still low. There are so many violation towards the regulation. Hence, it is good for BPOM to make cooperation with related parties like regional health service department, Indonesian Broadcasting Commission (KPI), Press Council and Association of Indonesian Advertising Enterprise) to educate and supervise medicine industries, medicine seller and society. ${ }^{15}$

\section{Implementation of Administration Sanction}

Administration sanction is further response toward inspection result, thus the sanctions are part of repressive law enforcement. Administration sanction is crucial in laws, because there is no use in stating obligations or prohibitions for society within administrative laws while it can't be implemented by state administration. Precisely, laws and regulations has ruled the obligation to have legalities and prohibition to act without any legalities, thus violating laws.

Authority and procedure to implement administration sanction in controlling OT is based on Article 188 paragraph (1) Act No. 36 of 2009 concerning in Health, stated that "Minister can take administrative action towards health practitioner and health service facilities that violate the regulation as stated in this act". This act clearly stated that attribution authority to establish administration law in form of warning letter and revocation of the license is under Minister of Health jurisdiction. Article 188 paragraph (2) stated: "Minister of Health can give the authority to non-ministerial government body, head of provincial department, or head of regency/city whose main task and function is about health".

The concept of representing the authority as stated in article 188 paragraph (2), support the action of BPOM and any related regional

14 Didik Hariyanto, "Memenangkan Persaingan Bisnis Produksi Farmasi Melalui Marketing Public Relation", Marketing Management Journal, Vol. 4 No.1, April 2009, Surabaya: Petra Christian University, page 42. governmental department to give administration sanction with their own portion of authorities. Regulation of administration sanction towards OT also stated in many regulation other than the Act itself. This is because Indonesia doesn't have special regulation concerning in pharmaceutical supply or medicines. Current regulation that covers this problem is Act no. 36 of 2009 concerning in Health. Administration sanction towards OT are usually in the following form.

The first, warning letter. Warning letter is the first step in giving administration sanction before other sanction are given. This procedure is implementation of principles of law state, principles of democracy, and principles of instrumental. Thus, warning letter must fulfill the principles of formal and material legality. BPOM issues the warning letter towards business actor as response to their violation, as well as towards society to give protection towards OT products. Warning towards society is given in form of public warning which mention OT brand and its violation. One of public warning issued by BPOM is Decision Letter of Head of BPOM No. HM03.05. 1.43.09.12.6081 on September 19, 2012.

Second, administrative coercion. This sanction is given in order to restore the casualties that caused by the violation. It is given by considering the condition and types of violation. Based on the inspection toward OT production facilities, it is known that $<70 \%$ OT production facilities doesn't meet the requirements within CPOTB (TMK). Details of violation includes: chemical-containing OT, OT TIE, improper sanitation and hygiene, violation of license, and other. Administrative coercion given to such violation can be fulfillment of requirements, marketing prohibition and/or revocation of OT, pulverization of OT, and/or force closing.

Third, revocation of license. Revocation of license is one of the heaviest sanction given towards OT violation, thus require deep consi-

15 Supardi Sudibyo, "Kajian Perundang-undangan tentang Iklan Obat dan Peran Serta Masyarakat Dalam Pengawasan”, Indonesian Pharmacy Journal, Vol. 1, No. 3, 2009, Jakarta: Research and Development of the Ministry of Healthh of the Republic of Indonesia, page 118. 
deration. This sanction are often addressed as unjust since majority of the business are UMKM that needs aid and assistant from government. Kelsen stated that law is different with justice. Justice is things related with public happiness. Hence, great sins of law maker is thinking that justice is what laws give. ${ }^{16}$

Fourth, law enforcement of criminal code. Implementation of laws and regulations are mean to achieve its goal, thus law enforcement is needed by implementation of criminal sanction towards violation because implementation of sanction is repartoir. Violation in OT include human error (employee, industry, seller, health service facilities) can cause a fatal injury even death. Thus violation in OT can be given both administration and criminal sanction.

Based on the attachment no. 117 Act No. 12 of 2011 concerning in Laws and Regulation stated that "Criminal code procedure only set within Act, regulation of Provincial government, and regulation of Regency/City Government". As we know that most regulation of OT only stated in Ministerial Regulation and Regulation of Head of BPOM, thus only administration sanction being regulated. While, criminal code for violation of OT is based on Act no. 36 of 2009 concerning in Health, precisely Article 196, Article 197 and Article 198, which regulate the violation in the following form: firts, producing or distributing pharmaceutical product and/or medical tools that doesn't fulfill the standard and/or requirements of safety, efficacy or benefits, and quality (Article 196); second, producing or distributing pharmaceutical products and/or medical tools that has no market license (Article 197); and third, incapable and Unauthorized pharmacist practices (Article 198).

\section{Closing \\ Conclusion}

Government instrument to control OT can be done through laws and regulations, license and legalization, and real action. First, laws and regulations and legalization of OT unable to

16 Husni Thamrin, "Penegakan Hukum Administrasi Terhadap Pelanggaran Hukum Lingkungan", PROGRESSIVE guarantee the safety, benefits, efficiency and affordability of OT for society because of OT businessman incapability to fulfill the requirements within the regulation. Second, government lack on assistant and supervision towards OT within society. Third, Society are lack on education and information of OT listed in public warning. Fourth, regulations concerning in OT are beleids regel/discretion, in form of Ministerial Regulation and Regulation of Head of BPOM, thus miss-match the principles of law making, especially principles of right officer/institution. Most law enforcement practices done by government towards OT is enforcement of administration law, since regulation of OT are mostly set by Regulation of Minister of Health and Regulation of Head of BPOM.

\section{Recommendation}

Evaluation towards requirements and standardize operational procedure (SOP) to obtain Business License, which is used as instrument to assist and control industries and business of OT. The requirements and SOP must be set within laws and regulations in national scope thus promoting equality throughout regional government. This way, it is expected to diminish problems of regional government to give licensing and legalization service.

Arrangements of traditional medicine has not been integrated with traditional health care, because health services are in many traditional societies into media for the circulation of traditional medicine can not be guaranteed safety and usefulness, so that the regulation needs to be made between the regulation of traditional medicine integrated with traditional health services.

\section{Bibliography}

BPOM, 2011, Profil Pengawasan Obat dan Makanan Tahun 2010, Jakarta: Ministry of Healthh of RI;

, 2014, Laporan Kinerja Badan Pengawasan Obat dan Makanan (BPOM) tahun 2013 dan

Scientific Journal, Vol.10, No. 30, December 2013, Banyuwangi: Seventeenth of March University, page 67. 
Triwulan I Tahun 2014, Jakarta: Ministry of Healthh of RI;

Hariyanto, Didik. "Memenangkan Persaingan Bisnis Produksi Farmasi Melalui Marketing Public Relation". Jurnal Managemen Pemasaran, Vol. 4 No.1, April 2009, Surabaya: Universitas Petra;

Rustia, Hana Nika. "Kontroversi Legalitas Praktik Kefarmasian Oleh Tenaga Keperawatan". Jurnal Aspirasi, Vol. 1, No. 1, June 2010, Jakarta: Secretariat-General DPR RI;

Dewoto, Hedi R. "Pengembangan Obat Tradisional Indonesia Menjadi Fitofarmaka" Majalah Obat Indonesia, Vol. 57, No. 7, July 2007, Jakarta: Indonesian Doctors Association;

Hemani. "Pengembangan Biofarmaka sebagai Obat Herbal Untuk Kesehatan". Bulletin of Agricultural Postharvest Technology, Vol. 7, No. 1, 2011. Bogor: Bogor Agricultural Institute;

Thamrin, Husni. "Penegakan Hukum Administrasi Terhadap Pelanggaran Hukum Lingkungan". PROGRESSIVE Scientific Journal, Vol. 10, No. 30, December 2013. Banyuwangi: Seventeenth of March University;

Wardani, Kristiono R.S. Yuniar. "Faktor-Faktor Yang Berhubungan dengan Pola Pencarian Pengobatan ke Pelayanan Kesehatan Alternatif Pasien Suspek Tuberculosis Di Komunitas". Public Health Journal, Vol. 7,
No. 2, September 2013. Yogyakarta: Ahmad Dahlan University;

Wahyuningsih, Mae Sri Hartati. "Deskripsi Penelitian Dasar Herbal Medicine". Journal of Traditional Medicine Magazine, Vol. 6, No. 2, 2007. Yogyakarta: Gadjah Mada University;

Susanto, Rudy. Faisal Abdullah and Sabir Alwy. "Pengawasan Peredaran Obat Tradisional di Singkawang". Law Research Journal, Vol, 2, No. 2, 2013. Makassar: Hasanudin University;

Sembiring, Salmen. "Pengetahuan dan Pemanfaatan Metode Pengobatan Tradisional pada Masyarakat Desa Suka Nalu Kecamatan Barusjahe". Socilogy Perspective Journal, Vol. I, No. 1, 2013. Medan: North Sumatra University;

Sampurno. "Obat Herbal dalam Prespektif Medik dan Bisnis". Journal of Traditional Medicine Magazine, Vol. 12, No. 4, 2007. Yogyakarta: Gadjah Mada University;

Sudibyo, Supardi. "Kajian Perundang-undangan tentang Iklan Obat dan Peran Serta Masyarakat dalam Pengawasan". Indonesian Pharmacy Journal, Vol. 1, No. 3, 2009. Jakarta: Research and Development of the Ministry of Healthh of the Republic of Indonesia. 